\title{
Gestational Trophoblastic Tumor cM1a TNM Finding v7
}

National Cancer Institute

\section{Source}

National Cancer Institute. Gestational Trophoblastic Tumor CM1a TNM Finding v7. NCI

Thesaurus. Code C89708.

Gestational trophoblastic tumor with lung metastasis. (from AJCC 7th Ed.) 